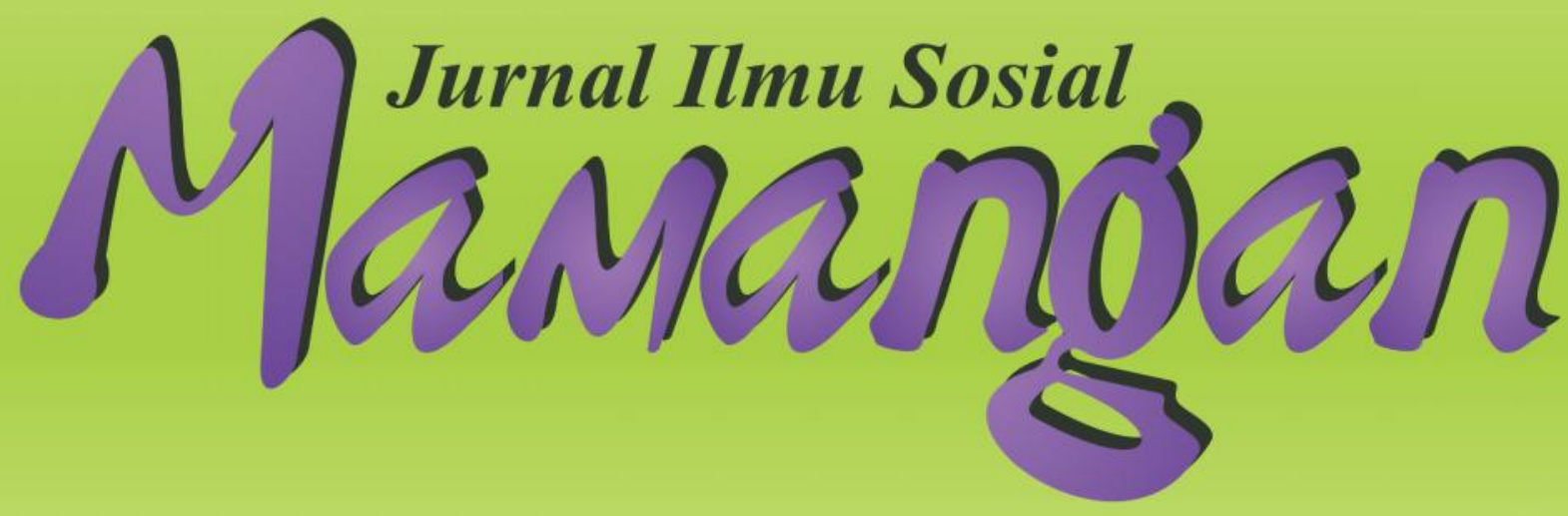

Efektifitas Program Keluarga Harapan (PKH) Dalam Upaya Pengentasan Kemiskinan Di Nagari Lagan Hilir, Kab. Pesisir selatan Apando Ekardo, Firdaus \& Nilda Elfemi

Pelaksanaan Program Corporate Social Responsibility (CSR) PT. VUM (Visi Utama Mandiri)

Yesi Herlina, Dian Anggraini Oktavia \& Elvawati

Sosial Ekonomi Perempuan Migran Kembali (Return Migrant) Jorong Kapuh, Nagari Sumani, Kab. Solok

Yuliana Nengrum, Yulkardi, Darmairal Rahmad

Pengemis Anak Di Pasar Raya Padang, Sumatera Barat

Mira Dona Eka Putri, Yulkardi \& Nilda Elfemi

Buruh Tani Jemputan Di Desa Sako Dua, Kec. Kayu Aro Barat, Kab. Kerinci

Wibi Wijaya, Zusmelia \& Elvawati

Konflik Pengelolaan Parkir Liar Di Pantai Purus, Kec. Padang Barat, Kota Padang

IImiati Amril, Ardi Abbas \& Surya Prahara 


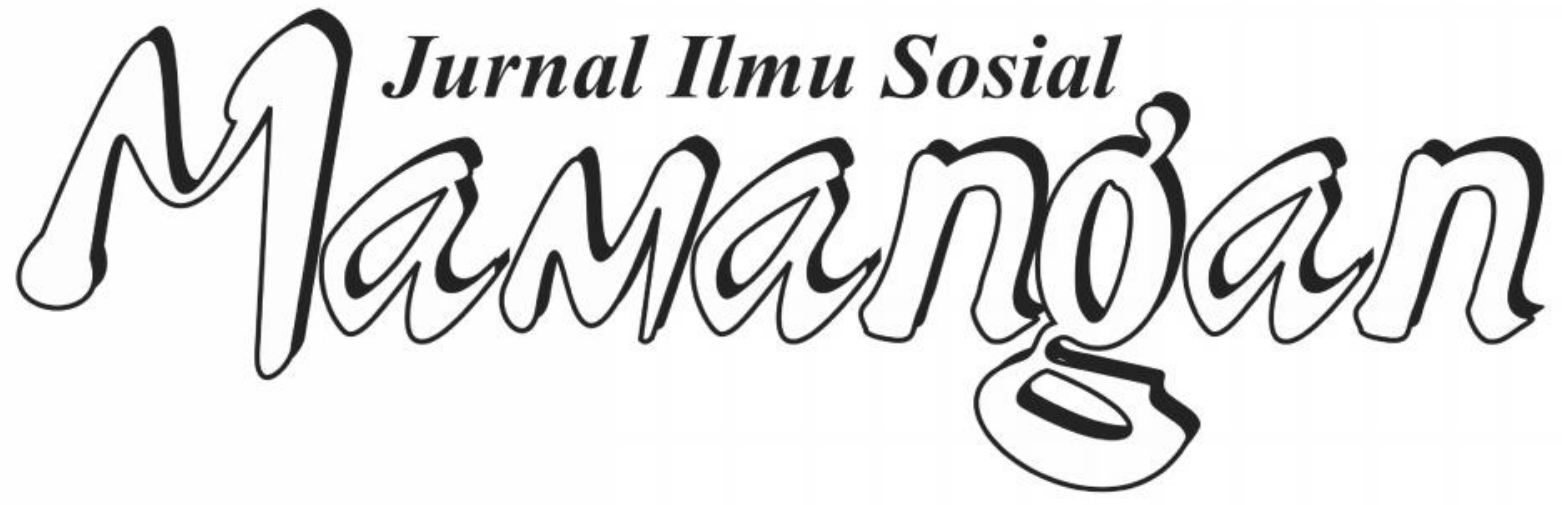




\section{Mitra Bestari}

Prof. Dr. Afrizal, MA. (FISIP, Unand Padang)

Dr. A. Latief Wiyata, M. Si. (Universitas Jember, Jember)

Prof. Dr. Badaruddin, M. Si. (FISIP, USU Medan)

Dr. Fikarwin Zuska, M. Si. (FISIP, USU Medan)

Nurus Shalihin, M. Si., Ph.D. (Fak. Ushuluddin IAIN Imam Bonjol Padang)

Dr. Semiarto A. Purwanto, M. Si. (FISIP, UI Jakarta)

Dr. Wahyu Wibowo, M. Si. (Universitas Nasional, Jakarta)

\section{Dewan Redaksi}

Dr. Zusmelia, M. Si.

Dr. Maihasni, M. Si.

Firdaus, S. Sos., M. Si.

\section{Pemimpin Redaksi}

Firdaus, S. Sos., M. Si.

\section{Anggota Redaksi}

Dian Kurnia Anggreta, S. Sos., M. Si.

Rinel Fitlayeni, S. Sos., MA.

Rio Tutri, M.Si.

Sri Rahayu, M. Pd.

Surya Prahara, SH.

Yuhelna, MA

ISSN: 2301-8496

Alamat Redaksi:

Laboratorium Program Studi Pendidikan Sosiologi, STKIP PGRI Sumbar Kampus STKIP PGRI, Jl. Gunung Pangilun, Padang, Sumatera Barat

Email: redaksimamangan@yahoo.com \& daus_gila @yahoo.com

Penerbit :

Program Studi Pendidikan Sosiologi, STKIP PGRI Padang 


\section{DAFTAR ISI}

Efektifitas Program Keluarga Harapan (PKH) Dalam Upaya Pengentasan Kemiskinan Di Nagari Lagan Hilir, Kab. Pesisir selatan

Apando Ekardo, Firdaus \& Nilda Elfemi ..

Pelaksanaan Program Corporate Social Responsibility (CSR) PT. VUM

Yesi Herlina, Dian Anggraini Oktavia \& Elvawati

Sosial Ekonomi Perempuan Migran Kembali (Return Migrant) Jorong Kapuh, Nagari Sumani, Kab. Solok

Yuliana Nengrum, Yulkardi, Darmairal Rahmad

Pengemis Anak Di Pasar Raya Padang, Sumatera Barat

Mira Dona Eka Putri, Yulkardi \& Nilda Elfemi

Buruh Tani Jemputan Di Desa Sako Dua, Kec. Kayu Aro Barat, Kab. Kerinci

Wibi Wijaya, Zusmelia \& Elvawati.

Konflik Pengelolaan Parkir Liar Di Pantai Purus, Kec. Padang Barat, Kota Padang

Ilmiati Amril, Ardi Abbas \& Surya Prahara

$40-48$ 


\title{
KONFLIK PENGELOLAAN PARKIR LIAR DI PANTAI PURUS, KEC. PADANG BARAT, KOTA PADANG
}

\author{
Ilmiati Amril ${ }^{1}$, Ardi Abbas ${ }^{2}$ \& Surya Prahara ${ }^{3}$ \\ $1 \& 3$ Sekolah Tinggi Keguruan dan Ilmu Pendidikan (STKIP) PGRI Sumatera Barat \\ 2 Sosiologi, Universitas Andalas
}

\begin{abstract}
This article aim to describe the conflict of illegal parking management ini Purus beach, Padang.. Research conducted with qualitative approach through descriptive type. Informants selected with purposive sampling. Data collected throught partisipative observation, indeepth interview and study document. The result is illegal parking in Purus started since 2008 and growing in 2013. Conlict is between illegal parking attendants and the owner of the vehicle, where the vehicle owner loses something when parking, conflict is between illegal parking attendant and UPT parking in the process of demolition. Conflict resolution between between illegal parking attendant and the owner of the vehicle is throught conciliation and conflict resolution between UPT parking with illegal parking attendants thrught pursuing cooperation strategy
\end{abstract}

\section{Kata Kunci : Conflict, Parking Management,Illegal Parking}

\begin{abstract}
ABSTRAK
Penelitian ini bertujuan untuk mendeskripsikan konflik pengelolaan parkir liar di Purus Padang. Pendekatan yang digunakan dalam penelitian ini adalah kualitatif dengan tipe deskriptif analisis. Pemilihan informan mengggunakan teknik purpossive sampling. Metode yang digunakan untuk pengumpulan data dilakukan dengan cara observasi berperan serta terbatas, wawancara mendalam (Indepth Interview) dan studi dokumen. Hasil penelitian menunjukkan bahwa munculnya parkir liar di Pantai Purus berawal semenjak jembatan penghubung dibangun pada tahun 2008 dan berkembang pada tahun 2013. Bentuk konflik yang terjadi dalam pengelolaan parkir liar adalah konflik antara petugas parkir liar dengan pemilik kendaraan, dimana pemilik kendaraan kehilangan barangnya disaat parkir, lalu konflik petugas parkir liar dengan UPT perparkiran dalam proses penertiban. Upaya penyelesaian konflik antara petugas parkir liar dengan pemilik kendaraan dengan cara konsiliasi dan upaya penyelesaian konflik petugas parkir liar dengan UPT Perparkiran dengan melakukan strategi kooperasi
\end{abstract}

\section{Kata Kunci : Konflik, Pengelolaan Parkir, Parkir Liar}

\section{PENDAHULUAN}

Kota seringkali dipahami sebagai bentuk kehidupan masyarakat yang sangat individual, penuh kemewahan, gedunggedung yang menjulang tinggi, perkantoran yang mewah, kendaraan yang lalu-lalang hingga mengundang kemacetan. Salah satu permasalahan yang cukup kompleks di perkotaan adalah masalah transportasi. Berbagai permasalahan muncul, seperti seringnya melihat lalu-lalang kendaraan bermotor yang memadati jalanan, kemacetan diberbagai ruas jalan yang diakibatkan parkir dan berpotensi 
menyebabkan kecelakaan (Oktapriza, 2007).

Perparkiran merupakan masalah yang sering dijumpai dalam sistem transportasi. Masalah perparkiran tersebut akhir-akhir ini sangat mempengaruhi pergerakan kendaraan, dimana kendaraan yang melewati tempat-tempat yang mempunyai aktifitas tinggi laju pergerakannya akan terhambat oleh yang parkir di badan jalan, sehingga hal ini dapat berpotensi menyebabkan kecelakaan (Dewi, 2012).

Selain itu secara ekonomi parkir berpotensi meningkatkan pendapatan daerah. Tidak semua tempat parkir dikendalikan secara resmi sehingga sering muncul petugas parkir tidak resmi yang mengumpulkan seluruh pendapatannya ke dalam kantong sendiri (Yanti, 2012)

Meningkatnya aktifitas pemarkiran liar ini pun sepertinya digunakan oleh para pemilik kendaraan yang melihat deretan kendaraan yang terparkir di kawasan tersebut. Tentunya fungsi dan tanggung jawab dari pemerintah yang mengurusi masalah parkir dipertanyakan untuk menertibkan oknum-oknum petugas parkir liar yang menggunakan tepi jalan dibeberapa tempat-tempat keramaian tanpa pernah memperhatikan aturan yang telah dibuat oleh pemerintah untuk daerahdaerah yang memang menjadi tempat umum atau publik (Yunus, 2012)

Berdasarkan survei awal yang peneliti lakukan pada tanggal 29 Maret 2014 disepanjang Pantai Purus Padang lebih kurang $3 \mathrm{~km}$, bahwa terdapat 25 orang petugas parkir liar, dan mereka berasal dari warga Purus. Tarif yang ditentukan untuk motor Rp.1000 hingga Rp.2.000 sekali parkir. Sementara untuk mobil Rp.3000 hingga Rp.4.000 sekali parkir dan hari libur mencapai Rp.5.000 untuk roda empat. Pengguna jasa parkir tidak diberikan karcis resmi sebagai bukti bayar retribusi parkir ke Pemko. Konflik pengelolaan parkir liar di Pantai Purus yaitu pada Purus Atas terjadi karena perbedaan kepentingan antara petugas parkir liar dan pemilik kendaraan serta tokoh masyarakat, pemuda dan Dishubkominfo Padang. Petugas parkir membantu pengendara dalam memarkirkan kendaraannya, ia mempunyai kepentingan dalam memungut biaya parkir dengan tarif yang tidak sesuai dan tidak memberikan karcis parkir. Tokoh masyarakat serta ketua pemuda hanya melegalkan para pengguna kendaraan untuk menempati daerah yang belum diresmikan untuk tempat parkir.

Berangkat dari permasalahan di atas, maka penelitian ini mengkaji lebih lanjut tentang parkir liar. Oleh sebab itu penelitian ini diberi judul "Konflik dalam Pengelolaan Parkir Liar di Pantai Purus Kelurahan Rimbo Kaluang Kecamatan Padang Barat Kota Padang". Berdasarkan dari penjelasan dilatar belakang maka pertanyaan dalam penelitian ini adalah: Bagaimana Konflik dalam Pengelolaan Parkir Liar di Pantai Purus Kelurahan Rimbo Kaluang Kecamatan Padang Barat Kota Padang. Tujuan umum yang ingin dicapai dalam penelitian ini adalah Mendeskripsikan konflik dalam pengelolaan parkir liar di Pantai Purus Kelurahan Rimbo Kaluang Kecamatan Padang Barat Kota Padang.

Tujuan khususnya mendeskripsikan keberadaan parkir liar di Pantai Purus Kota Padang, mendeskripsikan kepentingan pihak-pihak yang terlibat dengan keberadaan parkir liar di Pantai Purus Kota Padang, mendeskripsikan bentuk konflik parkir liar dan upaya penyelesaiannya.

\section{TINJAUAN PUSTAKA}

Menurut Undang-Undang Nomor 22 Tahun 2009 tentang Lalu Lintas dan Angkutan Jalan Pasal 1 Nomor 15 yang menjelaskan bahwa parkir adalah keadaan kendaraan berhenti atau tidak bergerak untuk beberapa saat dan ditinggalkan pengemudinya. Parkir adalah keadaan tidak bergerak suatu kendaraan yang bersifat sementara dengan kondisi khusus (Perda Kota Padang Nomor 11 tahun 2005 BAB I Ketentuan Umum Pasal 1 Nomor 15 Tentang Ketertiban Umum dan Ketentraman Masyarakat). Berdasarkan keputusan Direktur Jenderal Perhubungan Darat Nomor 272/HK.105/DRJD/96 tentang pedoman teknis Penyelenggaraan Fasilitas Parkir, penyelenggaraan perparkiran merupakan suatu metode perencanaan dalam menyelenggarakan fasilitas parkir kendaraan, baik di badan jalan maupun di luar jalan. Jenis peruntukan kebutuhan parkir dapat ditentukan sebagai berikut :

1. Kegiatan parkir tetap, yang terdiri dari : pusat perdagangan, pusat perkantoran pemerintahan atau swasta, pusat 
perdagangan eceran atau pasar swalayan, pasar, sekolah, tempat rekreasi, hotel dan tempat penginapan, serta rumah sakit.

2. Kegiatan parkir yang bersifat sementara seperti : bioskop, tempat pertunjukkan, tempat pertandingan olahraga, rumah ibadah, dan lain-lain.

Parkir adalah tempat pemberhentian kendaraan dalam jangka waktu pendek atau lama, sesuai dengan kebutuhan pengendara. Parkir merupakan salah satu unsur prasarana transportasi yang tidak terpisahkan dari sistem jaringan transportasi, sehingga pengaturan parkir akan mempengaruhi kinerja suatu jaringan, terutama jaringan jalan raya.

Menurut penempatannya parkir dikategorikan sebagai berikut:

a. Parkir di tepi jalan (on-street parking). Yakni parkir dengan menggunakan badan jalan sebagai tempat parkir.

Kerugian :

1) Mengganggu lalu lintas

2) Mengurangi kapasitas jalan karena adanya pengurangan lebar lajur lalu lintas

3) Meningkatkan kemungkinan terjadinya kecelakaan

Keuntungan :

1) Murah tanpa investasi tambahan

2) Bagi pengguna tempat parkir bisa lebih dekat dan mudah

Posisi parkir :

1) Sejajar dengan sumbu jalan

2) Tegak lurus sumbu jalan

3) Membuat sudut dengan sumbu jalan

b. Parkir di luar badan jalan (off-street parking). Yakni parkir kendaraan di luar badan jalan bisa di halaman gedung perkantoran, supermarket, atau pada taman parkir.

Keuntungan :

1) Tidak mengganggu lalu lintas

2) Faktor keamanan lebih tinggi

Kerugian :

1) Perlu biaya investasi awal yang besar

2) Bagi pengguna dirasakan kurang praktis, apalagi kepentingannya hanya sebentar saja

Selain berdasarkan penempatan, berdasarkan statusnya parkir terdiri atas :

a. Parkir umum, biasanya dikelola oleh pemerintah daerah.

b. Parkir khusus, dikelola oleh swasta.

c. Parkir darurat, diselenggarakan karena adanya kegiatan incidental.

d. Taman Parkir, dikelola oleh pemerintah daerah.

e. Gedung Parkir, biasanya diselenggarakan oleh pemerintah daerah dan pengelolaannya oleh swasta.

Berdasarkan jenis kendaraan yang parkir, parkir dibagi atas :

a. Kendaraan tidak bermesin (sepeda)

b. Sepeda motor

c. Mobil

Berdasarkan tujuannya, jenis parkir terdiri atas :

a. Parkir penumpang : untuk kebutuhan menaikkan dan menurunkan penumpang

b. Parkir barang : untuk kebutuhan bongkar muat barang

Berdasarkan jenis kepemilikan dan pengoperasian terdiri atas :
a. Milik swasta dan dikelola oleh swasta
b. Milik pemerintah daerah dan dikelola oleh pemda
c. Milik pemerintah daerah dan dikelola oleh swasta

\section{METODE PENELITIAN}

Penelitian ini menggunakan pendekatan kualitatif sedangkan tipe penelitian ini adalah deskriptif analisis. Jenis data yang digunakan yaitu data primer dan data sekunder. Teknik pengumpulan data adalah observasi, wawancara, dan studi dokumen.

\section{KEBERADAAN PARKIR LIAR DI PANTAI PURUS KOTA PADANG}

Munculnya parkir liar di Pantai Purus berawal sejak jembatan penghubung dibangun yaitu pada tahun 2008, ketika jembatan penghubung tersebut dibuka pada 
tahun 2013, dan pengunjung mulai berdatangan. Keadaan ini dijadikan peluang oleh warga setempat untuk mencari penghasilan sebagai jasa parkir walaupun dalam aktifitas ini mereka tidak memiliki izin dari aparat yang berwenang. Walaupun parkir ini belum memiliki izin dari aparat berwenang, namun parkir liar ini telah dikelola oleh warga setempat yaitu ketua pemuda. Ketua pemuda yang memberikan izin kepada warganya untuk menjadi petugas parkir di kawasannya yaitu di Purus Atas. Karena keberadaan parkir ini tidak resmi maka mereka tidak memiliki karcis parkir untuk diberikan kepada pengguna jasa mereka/pengunjung, hal ini terkadang mendapatkan tantangantantangan dari pengunjung. Selain karena tidak adanya karcis dari petugas parkir tantangan dari pengunjung juga terjadi karena petugas parkir secara langsung meminta uang parkir terlebih dahulu saat pengunjung baru datang. Ada kepentingan pihak-pihak yang terlibat dalam kemunculan parkir liar ini, hal ini akan dijelaskan dalam pembahasan berikut,

\section{KEPENTINGAN PIHAK-PIHAK YANG TERLIBAT \\ Petugas Parkir Liar}

Petugas parkir tidak resmi/ liar adalah petugas parkir yang namanya tidak terdaftar dari Unit Pelaksanaan Teknis (UPT) Perparkiran Dinas Perhubungan Komunikasi dan Informatika (Dishubkominfo) Kota Padang, dan tidak memenuhi syarat serta tanpa mengenakan atribut parkir dan tidak memberikan karcis parkir.

Petugas parkir membantu pengendara dalam memarkirkan kendaraannya, dimana ia mempunyai kepentingan untuk memungut biaya parkir, selain itu petugas parkir mencari kesempatan untuk mendapatkan keuntungan dengan mematok tarif yang tidak sesuai dengan aturan yang telah ditetapakan, petugas parkir inilah yang disebut petugas parkir liar. Ada beberapa alasan informan bekerja sebagai petugas parkir yaitu:

1) Untuk menambah penghasilan

Salah satu alasan bekerja sebagai petugas parkir liar ini adalah untuk menambah penghasilan. Ditemukan di lapangan bahwa orang yang bekerja sebagai petugas parkir adalah orang yang berlatar belakang tidak tamat sekolah. Oleh sebab itu, mereka bekerja sebagai petugas parkir untuk menambah penghsilannya dan juga untuk membantu orang tuanya. Hal ini diungkapkan oleh informan Yondri (18 tahun) wawancara Minggu 5 Juli 2014 dan beberapa informan lainnya juga menjelaskan hal yang hampir sama. Penjelasan Yondri adalah sebagai berikut,

"Awak ko baru lo nyo tukang parkir disiko, alasan awak manjadi tukang parkir ko kak a untuak manambah-nambah pitih lanjo se nyo, salain tu untuak mambantu urang gaek".

Artinya :

"Saya masih baru bekerja sebagai petugas parkir di lokasi ini, alasan saya bekerja tersebut untuk menambah penghasilan dan selain itu untuk membantu orang tua".

2) Tidak ada biaya untuk melanjutkan pendidikan

Anak putus sekolah merupakan keadaan dimana anak mengalami keterlantaran karena sikap dan perlakuan orang tua yang tidak memberikan perhatian yang layak terhadap proses tumbuh kembang anak tanpa memperhatikan hak-hak anak untuk mendapatkan pendidikan yang layak. Dalam penelitian di lapangan juga ditemukan anak yang putus sekolah dikarenakan tidak adanya biaya untuk melanjutkan pendidikan tersebut.

Selain tidak adanya biaya dari orang tua yang tidak mampu menyekolahkan anaknya, kurangnya minat untuk meraih pendidikan dari anak tersebut juga termasuk alasan bekerja sebagai petugas parkir liar.

3) Sebagai kerja sampingan

Setiap orang bekerja guna memenuhi kebutuhan hidupnya, tidak semua jenis pekerjaan dapat mencukupi kebutuhan seseorang, ada kalanya seseorang membutuhkan pekerjaan lain sebagai kerja sampingan, biasanya orang tersebut membutuhkan pekerjaan sampingan karena penghasilannya 
belum mencukupi untuk kebutuhannya sehari-hari. Ditemukan di lapangan bahwa masyarakat yang tinggal di Purus Atas umumnya bekerja sebagai nelayan, tukang ojek, satpam, berdagang di Pasar Pagi, dan sebagainya. Dengan alasan karena pekerjaan tetap yang mereka jalani tidak mencukupi untuk kebutuhan hidupnya, maka dari itu bekerja sampingan dapat menambah pendapatannya juga mereka lakukan. Salah satunya adalah sebagai petugas parkir liar. Pendapatan yang mereka peroleh sebagai petugas parkir liar ini adalah dengan kisaran Rp.50.000Rp.80.000 perhari saat pengunjung ramai, sedangkan di waktu pengunjung sepi pendapatannya dalam kisaran Rp.15.000-Rp.20.000 perhari.

Di dalam menjalankan aktifitasnya setiap hari, ada beberapa permasalahan yang dihadapi oleh petugas parkir liar dalam mengatur kendaraan yaitu :

a) Tempat parkir yang tidak teratur

Biasanya ketidakteraturan yang terjadi di tempat parkir karena petugas parkir yang tidak memandu pengguna jasa parkir dalam memarkirkan kendaraannya. Sehingga pengguna jasa parkir seenaknya sendiri memarkirkan kendaraannya, misalnya sepeda motor yang diparkir tidak sejajar, biasanya petugas parkir memindahkan kendaraan tersebut. Akan tetapi bagaimana jika sudah dikunci stangnya, sulit sekali bagi petugas parkir untuk memindahkannya.

Dengan begitu terlihat bahwa sarana atau fasilitas kurang baik karena dalam aturan parkir saja tidak ada bentuk tanggung jawab atau ganti kerugian oleh pemerintah, sedangkan tempat parkir para petugas parkir justru melarang untuk mengunci stang motor. Jika tempat parkir memungkinkan untuk menampung kendaraan serta jalur keluar masuknya kendaraan, maka seharusnya setiap kendaraan diperbolehkan untuk mengunci stang motornya demi keamanan kendaraan. Hal ini yang menyebabkan kepercayaan masyarakat yang kurang akan keamanan tempat parkir akibat buruknya fasilitas parkir. b) Masalah atribut seragam dan perlengkapan petugas parkir

Petugas parkir dalam melaksanakan tugas pelayanan jasa parkir diwajibkan memakai atribut seragam dan perlengkapan yang telah ditentukan oleh peraturan yang berlaku. Hal tersebut untuk menunjukkan identitas dan untuk membedakan antara petugas parkir dengan yang bukan petugas parkir. Pakaian seragam petugas parkir adalah berwarna orange.

Akan tetapi, dalam penelitian di lapangan petugas parkir tidak menggunakan seragam yang telah ditentukan. Selain itu, kelengkapan yang harus dibawa oleh petugas parkir dalam melaksanakan tugasnya pun tidak ada, misalnya saja mereka tidak membawa pluit, karcis parkir, rompi parkir dan id card atau tanda pengenal parkir.

c) Tarif parkir yang tidak sesuai dengan yang telah ditetapkan

Dalam ketentuan Peraturan Daerah Kota Padang Nomor 11 Tahun 2011 tentang Retribusi Jasa Umum sudah ditentukan mengenai tarif resmi yang harus dipungut oleh petugas parkir kepada pengguna jasa parkir. Akan tetapi, berbeda dengan apa yang terjadi di lapangan, seringkali petugas parkir meminta tarif parkir lebih tinggi dari ketentuan yang berlaku. Hal tersebut terjadi misalnya pada hari raya, tahun baru dan acara lain.

Petugas parkir sering memanfaatkan hal tersebut untuk memperoleh keuntungan pribadi, ada yang menaikan tarif parkir karena untuk mengejar setoran. Hal ini dijelaskan oleh Yunus (34 tahun) dan informan lainnya juga menjelaskan hal yang sama. Penjelasan informan adalah sebagai berikut,

"Kalau hari biasa uang parkir ini saya minta Rp.2000 untuk motor dan mobil Rp.3000. Tapi jika hari raya dan tahun baru, saya naikkan tarifnya sedikit, motor Rp.3000, dan mobil Rp.5000. Kami naikkan tarifnya ini karena orang ramai, seperti hari raya dan tahun baru ini ramai pengunjungnya. Kendaraan ini penuh karena orang-orang yang 
parkir disini. Saking ramainya pengunjung ini saya pun agak kesulitan untuk mengatur kendaraan yang keluar dan masuk ini".

Dari data yang diperoleh bisa disimpulkan bahwa petugas parkir menaikkan tarif parkir jika ada acara, hari raya dan juga tahun baru. Karena pada acara dan hari tertentulah membuat petugas parkir memperoleh pendapatan yang lebih dibandingkan hari-hari biasanya, ini disebabkan karena banyak pengunjung yang datang untuk berlibur di Pantai Purus tersebut terutama di Purus Atas. Pengunjung yang ramai serta kendaraan yang penuh membuat petugas parkir kesulitan untuk mengatur kendaraan yang parkir.

d) Kurangnya pengetahuan petugas parkir Salah satu masalah perparkiran yang sering terjadi diakibatkan kurangnya pengetahuan petugas parkir ataupun masyarakat tentang Peraturan Daerah Kota Padang Nomor 11 Tahun 2011 tentang Retribusi Jasa Umum. Selain itu petugas parkir juga harus dibekali dengan pengetahuan yang cukup dalam mengatur lalu lintas, agar dalam pelaksanaan tugasnya tidak menimbulkan kemacetan lalu lintas. Hal ini telah diatur dalam Undang-Undang Nomor 22 Tahun 2009 tentang Lalu Lintas dan Peraturan Daerah Kota Padang Nomor 4 Tahun 2013 Tentang Lalu Lintas.

Masih banyak petugas parkir yang hanya bermodal seragam dan karcis atau pluit saja dalam melaksanakan tugasnya. Sedangkan keahlian cara mengatur ataupun menata parkir pun masih kurang bahkan sepertinya petugas parkir ini tidak mempunyai kemampuan untuk mengatur lalu lintas, hanya mementingkan mobil ataupun kendaraan lainnya yang keluar dari tempat parkir, dari pada kendaraan yang lewat di jalan sehingga menimbulkan kemacetan. Petugas parkir yang resmi saja masih kurang pengetahuannya terhadap mengatur parkir dan lalu lintas, apalagi petugas parkir liar/ tidak resmi yang tidak tahu dengan aturan tersebut. Ditemukan di lapangan petugas parkir liar hanya menerima uang parkir saja, kemudian langsung pergi, dan mereka tidak membantu pemilik kendaraan untuk mengeluarkan motornya tersebut.

\section{Tokoh Masyarakat Setempat}

Dalam permasalahan yang diangkat, tokoh masyarakat juga memiliki kepentingan dalam mengelola perparkiran di Pantai Purus, terutama di Purus Atas, dimana tokoh masyarakat yang berkecimpung dalam permasalahan ini adalah Ketua RT/RW. Dalam penelitian di lapangan bahwa tokoh masyarakat ini melegalkan para pengguna kendaraan untuk menempati daerah yang belum diresmikan lokasi parkirnya oleh pemerintah.Walaupun telah melapor kepada pemerintah yang bersangkutan, namun sampai saat ini belum jelas penanganannya. Jadi parkir liar yang ada dikawasan tempat penelitian yaitu di Pasir Purus Atas yang mengelolanya adalah pemuda setempat yang memperoleh izin dari ketua RT/RW.

\section{Pemuda Setempat}

Pemuda setempat juga terlibat dalam masalah parkir liar ini, karena ketua pemuda mempunyai kepentingan untuk mengelola lahan parkir ini sebagai tempat perparkiran, warga setempat di Pasir Purus Atas yang menjadi petugas parkir harus melapor dulu sebelumnya kepada ketua pemuda tersebut. Dalam penelitian lapangan, ketua pemuda yang terlibat dalam masalah parkir liar ini adalah ketua pemuda RT/RW 02/IV. Hal ini sebagaimana yang diungkapkan oleh Bapak Mayulis, B (51 tahun) dan informan lainnya juga menjelaskan hal yang sama, penjelasannya adalah sebagai berikut,

"Bapak telah pergi ke Dinas Perhubungan, tapi dia yang meminta janji, bagaimana masalahnya disana bapak tidak tahu, katanya formulir untuk petugas parkir ini dishub yang akan memberikan lalu datadatanya juga untuk diisi, tapi sampai saat ini belum ada tanggapannya lagi hanya janjijanji saja. RT. 02 dan RT. 03 bapak 
yang ketua pemudanya, dan yang ini bapak mengelolanya apapun permasalahannya bapak yang turun tangan".

Berdasarkan semua sumber informasi, tergambar bahwa parkir liar di Pasir Purus Atas Kelurahan Rimbo Kaluang Kecamatan Padang Barat Kota Padang belum mendapatkan izin resmi dari Dishubkominfo Padang, walaupun telah melaporkannya, tapi belum terlihat kinerja Dishub dalam penanganan masalah parkir liar ini. Oleh sebab itu, lahan parkir yang di tempati oleh pengunjung merupakan sepenuhnya tanggung jawab dari Ketua Pemuda setempat. Dengan demikian, apapun yang terjadi merupakan tanggung jawab Ketua Pemuda. Konsekuensinya adalah siapapun yang bekerja sebagai petugas parkir harus melapor dulu kepada ketua pemuda setempat, supaya ketua pemuda mengetahui siapa-siapa saja orangnya, dan orang yang bekerja sebagai petugas parkir ini tidak boleh orang luar, harus orang yang tinggal di tempat tersebut. Menjadi petugas parkir pun harus bergantigantian, tidak boleh orangnya itu-itu saja dan orang yang sama sekali tidak bekerja serta tidak memiliki uang, maka diberikan pekerjaan sebagai petugas parkir.

Hal ini menggambarkan bahwa orang yang bekerja sebagai petugas parkir adalah orang yang tidak punya uang dan yang tidak bekerja, termasuk keluarganya yang miskin dan anak yatim, boleh bekerja sebagai petugas parkir setiap hari. Petugas parkir ini bekerja secara bergantian, semuanya mendapatkan kesempatan jika orang tersebut tergolong miskin.

\section{BENTUK KONFLIK PARKIR LIAR \\ Konflik Petugas Parkir VS Pemilik Kendaraan}

Konflik yang terjadi antara pemilik kendaraan dengan petugas parkir liar di Purus Atas dimana ketika pemilik kendaraan roda dua memarkirkan kendaraannya di lokasi tersebut, lalu pemilik kendaraan ini lupa membawa barangnya seperti telepon genggam atau handphone. Beberapa saat kemudian telepon genggamnya telah hilang di tempat parkiran tersebut. Barang yang hilang tersebut lalu dilaporkan kepada petugas parkir liar, namun tidak seorang pun petugas parkir liar yang mengakui atas kehilangan handphone tersebut. Hal ini membuat pemilik kendaraan marah kepada petugas parkir. Petugas parkir yang ada di lokasi melaporkan kejadian itu kepada ketua pemuda setempat.

\section{Konflik Petugas Parkir Liar VS UPT Perparkiran}

Konflik yang terjadi antara petugas parkir liar dengan pihak UPT Perparkiran yaitu di dalam melakukan penertiban parkir liar, penertiban parkir liar ini dilakukan kepada setiap parkir liar yang berada pada lokasi tersebut. Penertiban dan pengecekan parkir liar ini dilakukan oleh Pihak UPT Perparkiran yang bekerjasama dengan Tim Pengendalian Parkir. Di dalam melakukan penertiban ditemukan kendala sehingga menimbulkan konflik, kendalanya yaitu pada saat melakukan penertiban ada petugas parkir yang tidak mau diajak untuk bekerjasama. .

\section{UPAYA PENYELESAIAN KONFLIK PARKIR LIAR \\ Penyelesaian Konflik Petugas Parkir VS Pemilik Kendaraan}

Dalam penelitian ini, upaya penyelesaian konflik antara petugas parkir liar dengan pengguna jasa parkir yang dilakukan adalah dengan cara konsiliasi, konsiliasi merupakan suatu proses untuk memungkinkan pihak-pihak yang berkonflik untuk mendiskusikan berbagai kemungkinan pilihan dan mencapai penyelesaian melalui interaksi tatap muka. Konsiliasi tidak melibatkan pihak manapun dalam menyelesaikan suatu pertentangan. Konsiliasi lebih cenderung pada upaya damai yang dilakukan oleh pihak-pihak yang bertentangan terhadap pertentangan yang mereka alami.

Dalam menyelesaikan konflik tersebut ketua pemuda setempat menghimbau semua petugas parkir dan pengguna jasa parkir untuk mendiskusikan masalah tersebut agar segera diselesaikan. Dalam upaya penyelesaian konflik, pengguna jasa parkir meminta agar handphonenya segera ditemukan, namun petugas parkir serta ketua pemuda setempat telah berusaha untuk membantu mencarinya dan jika seandainya tidak ditemukan, maka 
bukanlah tanggung jawab petugas parkir untuk menggantinya.

Walaupun sudah berusaha mencarinya namun barang itu tidak dapat ditemukan. Ketua pemuda dan petugas parkir tidak bisa mengganti rugi barang yang hilang tersebut, karena ini merupakan kelalaian dari pengguna jasa parkir yang lupa membawa barangnya saat parkir di lokasi. Kemudian penyelesaian konflik yang dilakukan dengan cara mendiskusikan antara pihak yang berkonflik, dan menemukan solusi dari permasalahan pihak yang berkonflik dapat diselesaikan dengan cara damai.

\section{Penyelesaian Konflik Antara Petugas Parkir Liar VS UPT Perparkiran}

Penyelesaian konflik yang melibatkan pihak ketiga, menurut Dahrendorf dapat dilakukan dengan arbitrasi dan mediasi. Arbitrasi merupakan penyelesaian konflik oleh pihak ketiga yang memiliki sumber kekuasaan. Pihak ini mampu melakukan tekanan, intervensi terhadap pihak-pihak yang berkonflik agar pertentangan kepentingan dapat diselesaikan.

Sedangkan mediasi adalah penyelesaian konflik oleh pihak ketiga yang tidak mempunyai kekuasaan atau kemampuan untuk menindas pihak-pihak yang berkonflik agar konflik selesai. Menurut Dahrendorf, kelompok mediasi ini dikenal dengan kelompok penengah sementara kelompok arbitrasi adalah kelompok penghakiman. Ketiga bentuk penyelesaian pertentangan tersebut, yakni konsiliasi, mediasi, dan arbitrasi dapat dilaksanakan sebagai peraturan pertentangan secara berurutan atau dapat pula diterapkan secara berpisah-pisah menurut situasi yang dihadapi.

Pandangan Dahrendorf, mediasi merupakan bentuk yang paling ringan dari campur tangan pihak luar dalam menyelesaikan pertentangan. Kedua kelompok yang bertentangan sepakat untuk berkonsultasi dengan pihak luar yang diminta memberikan nasihat. Akan tetapi, nasehat tersebut tidak mempunyai kekuatan mengikat terhadap kelompok yang bertentangan. Model mediasi dinilai Dahrendorf dapat mengurangi sikap irrasional, menyingkirkan sikap nonrasional, menjajaki penyelesaian, membantu pengenduran perlahan, dan meningkatkan biaya pertentangan (Ritzer, 2012).

Dalam penelitian ini, strategi mengelola konflik petugas parkir liar dengan Dinas Perhubungan Kota Padang dilakukan dengan kooperasi. Strategi ini merupakan tindakan persuasi, negoisasi, dan musyawarah. Dalam melakukan penertiban parkir liar, Dinas Perhubungan bekerjasama dengan Tim Pengendalian Parkir yaitu Satpol PP dan Dinas Pasar. Wewenang terletak pada Dinas Perhubungan, karena Dinas Perhubungan yang menangani masalah tersebut. Setiap ada penertiban parkir liar Dinas Perhubungan Kota Padang pada umumnya melakukan pengecekan kepada setiap petugas-petugas parkir liar, pengecekan yang dilakukan seperti kelengkapan baju parkir, identitas diri dan karcis parkir. Parkir liar sudah jelas tidak memiliki kelengkapan itu, tindakan yang dilakukan oleh Dinas Perhubungan kepada petugas parkir liar dalam pengawasan dan penertiban parkir liar yaitu memberikan sosialisasi berupa teguran dan memberikan pengarahan.

\section{KESIMPULAN}

Tidak seperti iklan politik yang penuh dengan janji (Firdaus, 2013), parkir memberikan keuntungan secara cepat. Oleh karenanya, ruang-ruang dimanfaatkan untuk kepentingan parkir. Tidak terkecuali itu, di Pantai Purus parkir liar berawal semenjak jembatan penghubung dibangun maka ketika itulah masyarakat sekitar mulai mencari penghasilannya dengan bekerja sebagai petugas parkir. Lahan parkir yang belum memperoleh izin dari pihak yang berwenang namun telah diambil alih oleh ketua pemuda setempat. Ada yang menuntut dikarenakan oleh tempat parkir yang belum memperoleh izin dari pihak yang berwenang. Seperti: Ada yang merasa kesal serta terpaksa ketika membayar uang parkir, sebab petugas parkir terlebih dahulu meminta uang parkir diwaktu pengunjung baru datang serta bentuk konflik dengan pihak-pihak yang berkepentingan lainnya.

Konflik petugas parkir dengan pemilik kendaraan ketika parkir pemilik kendaraan kehilangan barangnya, lalu upaya penyelesaiannya dengan cara konsiliasi. Konflik kedua adalah petugas parkir dengan UPT Perparkiran di dalam menertibkan 
parkir liar ada yang tidak mau diajak bekerjasama. Upaya yang dilakukan dengan strategi kooperasi. Dalam melakukan penertiban ini, Dishub bekerjasama dengan Tim Pengendalian Parkir.

\section{DAFTAR PUSTAKA}

Dewi, R. (2012). Evaluasi Parkir di Pasar Blauran Kota Surabaya.

Firdaus, F. (2013). Parade Iklan Politik di Tahun Politik: Polarisasi Oenggunaan Iklan Politik Untuk Membangun Citra Menuju Pemilu 2014. Turast: Jurnal Penelitian Dan Pengabdian, 1(1), 81-
94.

Oktapriza, J. (2007). Studi Preferensi Pengemudi Terhadap Parkir di Badan Jalan di Kota Padang. padang. Ritzer, G. (2012). Teori Sosiologi (Dari Sosiologi Klasik Sampai Perkembangan Terakhir Post Modern). Yogyakarta: Pusataka Pelajar.

Yanti, R. (2012). Juru Parkir di Kota Makassar.

Yunus, D. S. (2012). Pengelolaan Retribusi Parkir di Kota Makassar (Studi Kasus di Perusahaan Daerah Parkir Makassar Raya). 


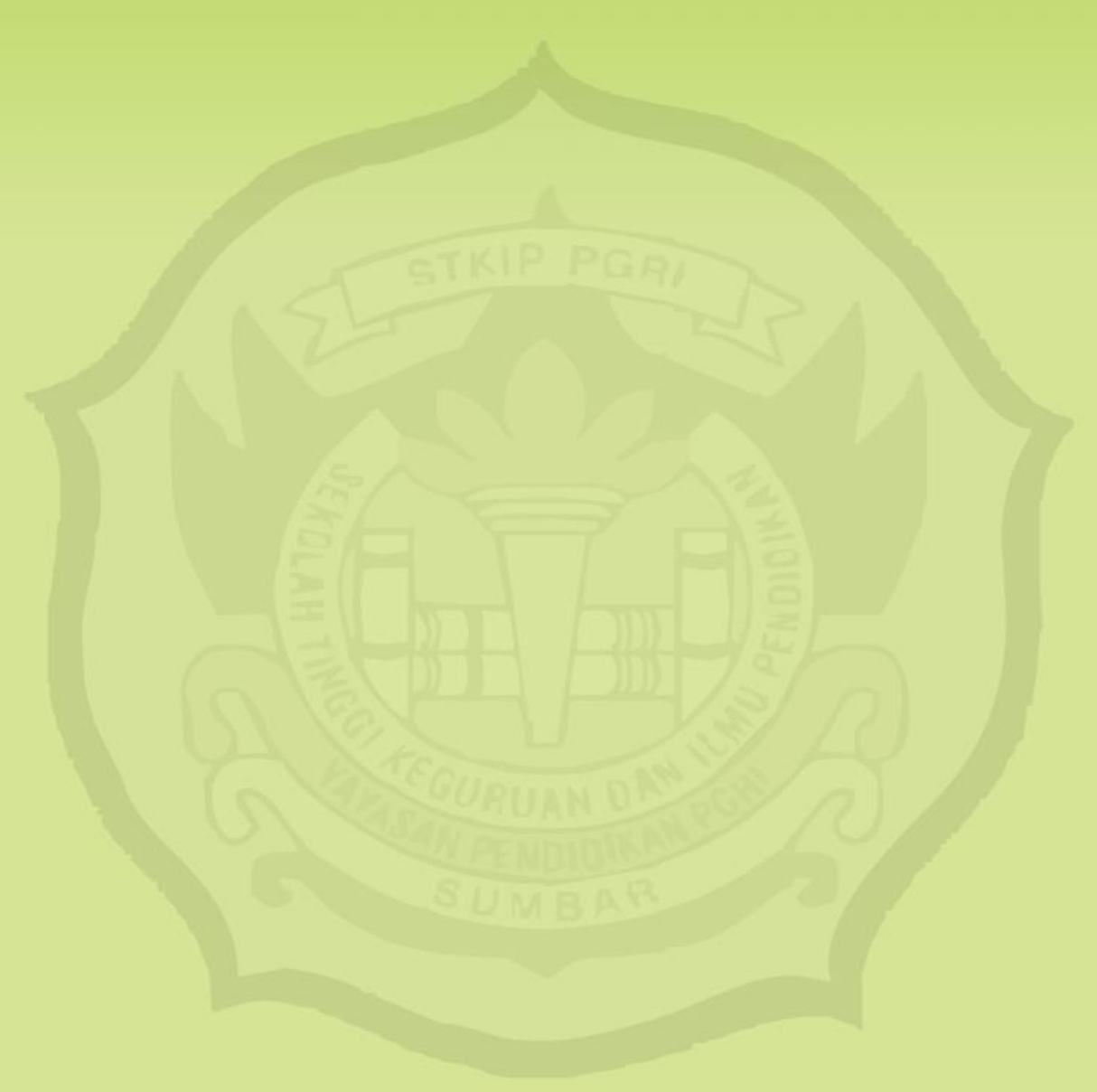

